\title{
A Systematic Review of Literature on Contested Heritage
}

\begin{abstract}
Contested heritage has increasingly been studied by scholars over the last two decades in multiple disciplines, however, there is still limited knowledge about what contested heritage is and how it is realized in society. Therefore, the purpose of this paper is to produce a systematic literature review on this topic to provide a holistic understanding of contested heritage, and delineate its current state, trends and gaps. Methodologically, four electronic databases were searched, and 102 journal articles published before 2020 were extracted. A content analysis of each article was then conducted to identify key themes and variables for classification. Findings show that while its research often lacks theoretical underpinnings, contested heritage is marked by its diversity and complexity as it becomes a global issue for both tourism and urbanization. By presenting a holistic understanding of contested heritage, this review offers an extensive investigation of the topic area to help move literature pertaining contested heritage forward.
\end{abstract}

Keywords: contested heritage, diversity, complexity, tourism, urbanization 


\section{Introduction}

The concept of heritage, both as tangible materials and intangible cultural practices, has continued to evolve as a result of people's shifting ideologies pertaining heritage. Its definition has evolved within a social, political and cultural context (Graham, 2002), to be known today as a cultural process in which meaning is continuously created, recreated and validated for the present (Macdonald, 2013; Smith 2006), and as a consumable experience created to serve many contemporary uses (Ashworth, 2014). The evolution of this concept is reflected in the shifting focus of heritage literature along three interrelated axes: from monuments to people, from objects to their functions, and from preservation to sustainable use and development (Harrison, 2013; Loulanski, 2006). The shift in focus from monuments to people is reflected in the growing literature discussing stakeholder involvement and community engagement in heritage management (e.g. Chinyele \& Lwoga, 2018; Thomas \& Banks, 2019). The second trend discusses the use of heritage to achieve various modern utility purposes as in the work of Galbo (2019) or Timothy (2018) for instance. The third focus shifts emphasis from heritage preservation to the reconciliation of preservation and the economic, social, and environmental aspects of development (e.g. Avni \& Teschner, 2019; Hosagrahar et al., 2016).

Given its wide range of stakeholders, different uses, and need to balance preservation and change, it is unsurprising that heritage has become an arena of contestation. The most representative work that conceptualizes this facet of heritage is Tunbridge and Ashworth's Dissonant Heritage (1996). In their work, dissonance, i.e. discordance and lack of agreement, is deemed intrinsic to the nature of heritage. As 'all the heritage is someone's heritage and then logically not someone else's' (p. 21), conflict inevitably presents itself in every heritage through aspects of ownership, interpretation and its multiple uses (Ingerpuu, 2018). Later, the contentious nature of heritage was addressed by Olsen and Timothy (2002) using the concept of 'contested heritage', which outlined two types of contestation. One type involved different 
social groups claiming the ownership of the same heritage but with different interpretations. The other type of contestation occurred when heritage was interpreted and used differently by various divisions within one group. The contestation of heritage was also addressed by Smith (2006) who explored the various ways in which authorized notions of heritage, and the values they represent, are contested. In the last twenty years, the concept of 'contested heritage', which may not always be named as such, has been a growing interest of scholars in various fields (e.g. Ristic \& Frank, 2019; Schramm, 2016). With increasing numbers of stakeholders from different sectors trying to manipulate heritage to fulfil multiple functions, it is not surprising that heritage is often contested. This contestation provides an unusual opportunity to examine cultural change through the perspectives and behaviours of the various stakeholders. The growing dissonance also prompts a deeper reflection on what heritage is and how it should be used, as it accentuates the contestation between continuity and change in heritage management.

Heritage, with all its dissonance, can still be successfully managed provided a comprehensive understanding of dissonance can be achieved. This study systematically investigates and synthesizes the extant literature concerning contested heritage, with the goal of obtaining a holistic understanding of the field. This review aims to answer the following three questions: 1) What characterizes contested heritage? 2) What are the factors that lead to heritage contestation? 3) What are the challenges and strategies in dealing with contested heritage? By looking at the evolving debate over more than two decades, this study places an emphasis on identifying, characterizing and summarizing the current understanding of contested heritage. It also tries to identify the major gaps in the extant literature to shed light on the potential directions for future studies.

Heritage contestation is not specific to any country, but rather a common phenomenon in pluralistic societies which allows us to understand the complexities and change of reality (Kisić, 2013). In times when heritage contestation is becoming increasingly salient in academic 
research, a greater understanding of this topic not only provides timely knowledge to deal with this urgent issue, but also pleas for more pluralist, dynamic and critical explorations of heritage to enable reconciliation and harmony amongst diverse people, cultures and values. The issue of contested heritage creates a space for mutual understanding, participative dialogue and cooperation. Furthermore, it offers valuable insight into heritage governance and policymaking at present, and highlights how it could contribute to peace-building in the future.

\section{Methodology}

A systematic quantitative literature review allows researchers to analyse existing academic literature in one specific field to produce a structured quantitative summary of the field (Pickering \& Byrne, 2014). This method has the advantage of providing a reproducible, reliable assessment of the current status of a research field in a way that ameliorates potential biases which occur in some traditional narrative style reviews (Collins \& Fauser, 2005). By using systematic methods to search and categorize the heterogeneous collection of literature, a comprehensive overview of the research field can be produced to help identify the gaps in the existing literature.

This study conducted a systematic literature review to map the landscape of current research concerning contested heritage. The final literature search was conducted in early January 2020, and all the articles published before 2020 were included in the research to present an up-to-date review. Original research papers, published in journals written in English, were obtained from searches on four electronic databases: Scopus, ProQuest Central, Science Direct, and Web of Science. Keywords used for the searches were ('contest*' OR 'contention*' OR 'dissonan*' OR 'conflict*' OR 'contradict*') AND ('heritage'), and articles with the search terms in the title, abstract and/or keywords were considered. It is important to note that these keywords were often used interchangeably within the relevant literature. Moreover, a limitation 
of the research is its exclusive use of online articles. However, as an increasing number of journals printed originally as a hard copy are also now available online, it is assumed that this bias will not significantly impact the results.

To ensure the quality of the research, only peer-reviewed articles were included. Aware that research pertaining contested heritage is conducted across diverse disciplines, limiting the research to peer reviewed articles only, also worked to ensure each selected paper has already been evaluated within its discipline, recognized as a suitable standard for publication within the academic literature (Guitart et al., 2012). The options available on the utilized databases of Scopus, Science Direct, and Web of Science that help limit and focus the research within social science discipline were also used as additional filters. The collated papers were then assessed based on their abstracts, and full texts when necessary.

\section{[ Fig. 1]}

Fig. 1 demonstrates the number of studies screened and excluded at different stages of the review. The literature search on the four databases resulted in 1769 records. After removing 263 duplicate references, the remaining 1506 records were screened against the literature selection criteria, where publications such as book reviews, commentaries, editorial notes and research note were eliminated. Despite the exclusion of these publications from results analysis, some of them were reviewed in the screening process as they were found to be helpful in developing greater understanding of the field. Articles from journals like Journal of Contemporary Criminal Justice, Journal of International Wildlife Law and Policy, Energy Research and Social Science were removed due to a lack of focus on heritage. Further selection criteria included the exclusion of studies in which the main research subject was not heritage, and studies in which heritage was not contested. For instance, some publications regarding the sustainable development of heritage tend to investigate heritage protection techniques rather 
than heritage per se (e.g. Karoglou et al., 2019). There are also many research papers which use 'conflict(s)' as a key word, but do not investigate heritage with reference to any conflict(s) because these studies focus on exploring the threats to heritage posed by violence or attack (e.g. Al Quntar \& Daniels, 2016; Brosché et al., 2017).

The screening process found 121 applicable papers, which were then retrieved for further review. The full text of these articles was used to determine if the research would be eligible for the final analysis. Articles that only included the searched terms in its context or findings and did not have a relative coverage in the investigation or discussion were discarded. For example, in Zhang and Smith's (2019) study, which discusses interrelations among stakeholders in heritage tourism, other than the inclusion of dissonance in the title, there was only one sentence that related to heritage dissonance in its discussion. This stated that 'there would seem to be a conflicting sense of heritage between that experienced within Xidi and Hongcun and that imposed by World Heritage policies and practice.' (p. 221) which did not seem to derive from the research itself. Thus, this paper, and others like it, were excluded from the review as they did not explicitly investigate heritage contestation.

Consequently, only 97 articles were identified as eligible for this study. As a supplement to electronic searching, the references of these applicable papers were then explored to source additional relevant studies. The cited references which were deemed relevant were imported into EndNote, and duplicates were removed and cross-referenced amongst the 97 eligible studies. The remaining papers were further screened, and five additional articles were found to be eligible for this study, increasing the total number of articles included in the final analysis to 102.

For the analysis of the literature, first, a summary of the basic information of each paper was entered into an Excel spreadsheet to create a table. This information included the authors, 
journal name, journal discipline (based on the main scope displayed on the journal website; for journals with overlapping research fields, the disciplinary affiliation of the first author was referred), year of publication, the location of contested heritage, and the types of heritage discussed. Then, these studies were assessed based on the focus of the research. The points of consideration used to evaluate the texts included: the definition of contested heritage, the factors that caused the contestation, the status of heritage when contestation occurred, the stakeholders involved, and the features of contested heritage. This information was subsequently extracted from each article and recorded in the summary table. A content analysis of this summary table was then conducted and the information within each category was coded, aggregated and abstracted into themes. The construction of these themes, and how they would be explored and quantified, was heavily discussed amongst the research team to enhance the reliability of the analysis and the relevance of the gaps identified within the study.

\section{Results}

\subsection{Overview of Studies Regarding Contested Heritage}

The 102 articles used in this study were retained from 58 journals and published before 2020 . The dominant disciplines that emerged were heritage (30 articles from three journals), tourism (30 articles in16 journals), urban and regional studies (15 articles in 13 journals), and archaeology (11 articles over 10 journals). Other disciplines such as politics, geography, anthropology, architecture, and history, were also presented with every journal within these disciplines differing from one another (Fig. 2). In terms of the development of this topic over time, results (Fig. 3) show that overall there was little interest in the topic prior to 2000, with only one article published in that year and seven published within the five years preceding 2000 . The number of articles doubled in the following five years. The next five years from 2006 to 2010 witnessed a general increase in the number of papers (17). The growing interest continued 
in the subsequent five years (20 articles), and has now reached a peak in the last five years (43 articles were published). The increasing engagement with the topic can be attributed to the growing manipulation of heritage as cultural, economic, social or political resources (Ashworth, 2014). The use of heritage as a means to assert, defend, or deny claims to power, land, legitimacy and so forth could also account for its increasing contestation (Silverman, 2011). The findings confirm a consistent interest from scholars over time and prove the interdisciplinary relevance of the concept, providing scholars from various fields, that wish to bring a more comprehensive and holistic view of the topic, a foundation of research to utilize in future collaboration and investigation.

\section{[Fig. 2 and Fig. 3]}

The geographic distribution of the locations studied in the research show that the issue of contested heritage is of interest in 41 countries, particularly within Asia and Europe (Fig. 4). Contested heritage in China attracted the most attention as it was examined in 16 out of 102 papers. The UK was studied in 11 articles, the USA was investigated in nine studies, while Italy appeared in five papers. Poland, Australia and Romania were presented in more than two articles. The prevalence of study in Europe could be explained by its dissonant history marked by the stigma of two world wars, genocide, colonialism and communism (Owsianowska, 2017). For Asia, its rapid economic growth, especially within its booming tourism industry, enables contested heritage to be foregrounded in literature (Cohen \& Cohen, 2012). The widespread geographical distribution of contested heritage indicates the international relevance of this study. However, the diverse context in which contestation occurs also alludes to the issue varying from case to case. Thus, it is important to understand both generalization and specialization when dealing with contested heritage.

[Fig. 4] 
The type of contested heritage examined in the reviewed literature ranged widely from significant monuments listed as a World Heritage Site by UNESCO, to prosaic sites known by few people. Within the reviewed articles, 97 papers studied cultural heritage, and of this, 93 explored tangible heritage (Fig. 5). Only five articles discussed natural heritage, three of them examined national parks (Kryder-Reid et al., 2018; Pocock \& Lilley, 2017; Weisse \& Ross, 2017) and two investigated urban waterfronts (Avni \& Teschner, 2019; Worden, 1996). There were five articles (Robertson, 2018; Rodenberg \& Wagenaar, 2016; Wu, 2019; Yamasaki, 2010; Zhu, 2015) that focussed on intangible cultural heritage, and one of which studied both tangible and intangible heritage (three explored rituals and events, one concerned heritage language, and another focussed on traditional art). Furthermore, in the 93 articles that examined tangible cultural heritage, 89 papers discussed built heritage, the other four discussed antiques, mummies, documents and frescoes (Kouri, 2017; Nakano, 2018; Plets et al., 2013; Tucker \& Carnegie, 2014). The review also highlighted that in 81 of the articles pertaining contested heritage, urban built heritage was of particular focus. Just eight papers investigated built heritage in rural areas. Additionally, more than half of the contested urban heritage sites discussed in the studies were associated with tragic events and portrayed a negative sentiment to some extent. These heritage sites were concerned with colonization (15 papers), war (14 papers), totalitarianism (eight papers), religious divide (seven papers), atrocity and death (four papers), and slavery (three papers). Other contested sites included historic neighbourhoods (eight papers), ethnic heritage (four papers), museums (three papers), archaeological sites (two papers), industrial heritage (two papers), and urban heritage in general (11 papers). The dominant focus on urban built heritage seems to reflect the threat posed to heritage during urban development. Meanwhile, the dark history attached to a heritage enables more contestation as the risks of removing its contentious historic contexts are higher (Roushanzamir 
\& Kreshel, 2001). Consequently, attention should be given to heritage in sites of urban development with consideration for its sensitive conservation.

[Fig. 5]

Regarding the research method, nearly all the reviewed literature used qualitative data, or a combination of qualitative and quantitative data, with only two studies purely using quantitative data. Research data was collected using a wide range of social science methods: case studies, fieldwork, text analysis, interviews and surveys (Fig. 6). There were 79 papers using the case study method and among them 61 adopted the single-case design. Studies using a multiple-case design included the comparison of two cases (nine articles), three cases (three articles), and more than three cases (eight articles). The number of multiple-case papers that studied cases from the same country was twice as high as those comparing cases in different countries. The major adoption of single-case design and less comparison of cases across different countries among the reviewed papers highlight the diversity of contested heritage and alludes to the difficulty of its transferability, which requires its management to be fully known. Interviews and fieldwork, including site visits, direct observation and informal interviews, were used in 50 and 35 papers respectively. There were 29 articles utilizing text analysis and texts were obtained from official documents, promotional materials, archives, press reports and websites. Only ten papers used surveys, souring data from questionnaires and guestbooks. The evident preference for qualitative methods in contested heritage studies is likely to be explained by the capabilities of qualitative analysis which enables a deeper understanding of the dissonance to be explored. This alludes to the complexity of heritage contestation.

\section{[Fig. 6]}

In regard to the definition of contested heritage, there is a tendency for authors to write about contested heritage, whilst rarely defining the concept. Among the 102 reviewed articles, 
only 14 papers presented a definition of the concept despite 17 articles readily using the term 'contested heritage' and 10 studies using 'dissonant heritage' in their titles. Although 'contested heritage' and 'dissonant heritage' were interchangeably used by many studies, a subtle difference between the two terms was found. Studies using 'dissonant heritage' were more likely to focus on negative and unwanted heritage, therefore, the term was frequently used in studies with post-war, post-colonial and post-catastrophe contexts (e.g. Ashworth, 2002; Battilani et al., 2018; Pavličić, 2016). Articles that preferred using the term 'contested heritage' also covered these contexts, but the investigated heritage tended to be more neutral and broader, thus, historic neighbourhoods, traditional rituals, religious sites and antiques were all included in these studies (e.g. Cheung, 1999; Harrison, 2004; Kouri, 2017; Wu, 2019).

\section{[Table 1]}

Table 1 shows the definitions presented by the 14 papers. There was just one article that stated the definition of 'contested heritage' (Corsale \& Krakover, 2018). The other 13 papers defined the term 'dissonant heritage', but only two of them presented their own definitions (Bruce \& Creighton, 2006; Lemelin et al. 2013), one of which was also quoted by another study. The remaining 10 papers all cited the pioneering work of Tunbridge and Ashworth (1996) in which the concept was deeply and comprehensively investigated. Despite the citation of the same work when defining 'dissonant heritage', the focus deriving from the definition in the 10 papers varied from disagreement between people to the inconsistency in the past and present meanings of heritage. Thus, there is no unanimous definition.

Despite its varied definitions, there is some indication as to what constitutes contested heritage. Firstly, the contestation of heritage is related to its stakeholders. It is the disagreement between or within stakeholder groups that results in the tensions and conflicts of heritage (Timothy \& Nyaupane, 2009). Secondly, every step of heritagization may lead to its 
contestation: from heritage creation, interpretation, and presentation to its ownership, marketing and tourism (Ingerpuu, 2018). Finally, the contestation of heritage stems from the change of time. Since heritage is created, shaped and managed in response to the demands and values of a certain period (Graham \& Howard, 2008), there could be discordance between past and present heritage. Understanding these key elements allows for effectiveness in contested heritage management.

In order to gain a better understanding of contested heritage, this paper discusses the main elements further, based on the following themes: 1) contestation in different heritage development processes; 2) stakeholders of contested heritage; 3) features of contested heritage; and 4) theories concerning contested heritage.

\subsection{Contestation in Different Heritage Development Processes}

\subsubsection{Contestation in Different Tourism Stages}

The literature review demonstrates that contestation can occur at different stages of heritage development. Because the role of heritage is at the heart of cultural tourism (Nuryanti, 1996), most scholars discussed contestation within the context of heritage's tourism development (56 articles). Therefore, R.W. Butler's (1980) concept of Tourism Area Life Cycle (TALC) was used as a reference to understand the contestation in different tourism development stages. Butler's concept ties in with the economics theory of the product life cycle and is widely used to study different types of tourism attractions and products. Since heritage is often treated as a commodity in contemporary society for economic uses, especially as tourism sites (Ashworth \& Tunbridge, 2000), the TALC model was deemed relevant for this analysis. Due to the difficulty in identifying the specific tourism stage in which contested heritage forms, based on the reviewed papers and the six phases of the TALC model, a simplified version of the original model (Johnston, 2001) with three eras, namely pre-tourism era, tourism era and post-tourism 
era was applied (Fig. 7). According to Johnston (2001), the pre-tourism era is theorized to surpass the exploration phase, extending through into the involvement phase with the domination of an unchanged institution; a tourism era will carry on through the maturity epoch and may even include a post-stagnation phase; and a post-tourism period starts when a new institution begins to dominate at the locale.

[Fig. 7]

There were 14 papers investigating contested heritage in the pre-tourism era. Due to the different perceptions of heritage values, contestation mainly occurred in the process to transform heritage resources into tourism products. During the process, whether the heritage resource should be exploited as a tourism product (Battilani et al., 2018; Ivanova, 2017) and how to develop the heritage resource (Su, 2011; Van Dyke, 2017) had given rise to dissonance among stakeholders. Marginalization of the views from local community were also present in this stage (Oakes, 2013).

The contestation of heritage during the tourism era was highlighted in 58 articles. A dominant contestation in this phase stemmed from the interpretation of heritage. This interpretation was contentious in three aspects. The first concerned the authenticity of interpretation. Heritage interpretation is usually focused on the promotion of heritage, meaning that sometimes the 'real' history is discarded or even distorted, and the interpretation subsequently becomes accused of losing its authenticity (Chen \& Mele, 2017; Gough, 2007; Maior-Barron, 2019). The second contentious aspect of heritage pertained the selectivity of its interpretation. The interpretation of heritage can sometimes erase partial or all undesirable pasts for purposes such as national identity building, and 'forgetting' unwanted memories and histories (Best \& Phulgence, 2013; Light, 2000). In addition, the focus on interpreting solely universal values of heritage, that ignore the values perceived by local community, has also led 
to contestation (Al Rabady, 2013; Tucker \& Carnegie, 2014). The third aspect of the contestation centred around the contradiction of interpretations. Due to the competing claims of heritage ownership among different social groups, especially religious groups, each group tries to present the interpretation from its own perspective (Corsale \& Krakover, 2018; Olsen \& Timothy, 2002). Another contention in this stage stemmed from the different views on the heritage product being protected and promoted. Heritage producers are inclined to focus on what might attract international tourists which can often contradict the interests of the local people (Hellman, 2017; Thompson, 2004).

There was only one article that researched contested heritage in the post-tourism era. It denoted that heritage was contested due to the disinheritance of contributions made by the forced workers and labourers during Nazi's occupation of British Channel Islands (Carr, 2010).

\subsubsection{Contestation in Different Management Status}

Another finding of this literature review reflects the importance of status in heritage. There are five main statuses in which a heritage can be stamped with: preserved; restored; reconstructed; regenerated; and demolished (Fig. 8). The preservation of heritage refers to 'maintaining the fabric of a place in its existing state and retarding deterioration' (Burra Charter, Article 1.6). The restoration of heritage means 'returning the existing fabric of a place to a known earlier state by removing accretions or by reassembling existing components without the introduction of new material' (Burra Charter, Article 1.7). Reconstruction of heritage looks at 'returning a place as nearly as possible to a known earlier state and is distinguished by the introduction of materials (new or old) into the fabric' (Burra Charter, Article 1.8). Heritage-led regeneration refers to 'initiatives where the driver for the social, economic and cultural revival of a declined urban or rural area is the heritage that makes a local place distinct' (Fouseki \& Nicolau, 2018). 
Although regeneration may entail all previously mentioned statues, it is listed separately due to its high relevance in tourism.

[Fig. 8]

Preservation, as a heritage status, appeared in 63 articles out of 102. There were five main factors, established from the review, that lead to contestation. The first was the divergent values and meanings of heritage perceived by stakeholders (Graham, 1996; Muzaini, 2017). Due to these differing perception, questions surrounding whether the heritage should be preserved (Johnson, 2014; While, 2007), what value should be promoted in its preservation (Gadsby \& Chidester, 2011; Tucker \& Carnegie, 2014), and how to manage the preserved heritage (Hellman, 2017; Nyaupane, 2009) all led to forming a rivalry among various parties. The second factor concerned the competing interests of the stakeholders throughout the heritage process (Cheung, 1999; Suntikul \& Jachna, 2013). For example, Putra and Hitchcock (2005) examined the conflicting interests over Besakih's World Heritage nomination and found that governments wanted to turn the temple into a national monument to attract tourists, while religious bodies and intellectuals feared that the religious significance of the site would be compromised by this. The third factor pertained the marginalization of certain stakeholders (Harrison, 2004), mainly seen in the narrative (Lemelin et al., 2013; Lemelin \& Johansen, 2014) and management (Corsale \& Krakover, 2018; Hall, 2019) of preserved heritage. The fourth factor was the multiple uses of heritage. Contestation occurred where preserved heritage was used to achieve political (Robertson, 2018), economic (Banaszkiewicz, 2017) and social agendas (Malan, 2004). The last factor that led to contestation in heritage preservation was linked to ownership of heritage (Olsen \& Timothy, 2002; Wu, 2019).

Contestation in the restoration status was investigated in 13 articles. One of the reasons why heritage was often restored, as reflected in the studies, was the changing perception of its 
value (Chen \& Mele, 2017). The potential for heritage to promote tourism was also a major factor that contributed to heritage restoration (Zhu, 2018). Disputes over the restored heritage derived from the different values of the stakeholders (Ingerpuu, 2018; Jacob, 2010), and the perceived loss of authenticity as a result of the restoration process (Bruce \& Creighton, 2006; Zhang \& Wu, 2016).

There were five articles that discussed heritage reconstruction and its controversy. The conflicting interests among stakeholders (Feighery, 2011; Halevi, 2015; Owsianowska, 2017) and the loss of heritage authenticity (Bruce \& Creighton, 2006; Su, 2011) resulted in contestation in reconstruction status. It was found that in some cases the interests of decisionmakers were more influential on the final outcome than the value of the heritage per se (Halevi, 2015; Su, 2011).

The contention deriving from heritage-led regeneration was examined in 18 articles. Tensions emerged around three aspects. First, what was worth keeping in the regeneration process was under debate among stakeholders that had different understandings of heritage value and thus conflicting interests (Al Rabady, 2013; Logan, 1996). Second, the market-led approach that dominated regeneration projects often ignored the interests and needs of the local community, consequently resulting in conflict (Su, 2011; Zhang \& Li, 2016). Finally, in order to adapt to contemporary needs, the re-use and rebranding of heritage, as a catalyst for the regeneration process, was also a source of dissonance (Chen \& Mele, 2017; Ingerpuu, 2018).

The conflicts caused by heritage demolition was studied in six articles, all of which explored instances where heritage was demolished to give way to modern urban development (e.g. Dawood et al., 2011; Esposito \& Fauveaud, 2019; Wang \& Aoki, 2019). Contention existed between governments who intended to demolish heritage and conservationists who strived to protect the heritage (Beaumont, 2009; Leung, 2019; Zhang \& Li, 2016). 
The various factors that lead to heritage contestation during different heritage development stages demonstrates the complexity of the issue, while also highlighting the limited research that explores how these factors interact with each other both within the same stage and across different stages. For example, how does the perception of heritage value affect the preferences for heritage use? How could the factors that lead to contestation in the pre-tourism stage influence the contestation in the tourism and post-tourism eras? Thus, a more integrated and dynamic perspective on contested heritage is encouraged in future research. In addition, heritage contestation is multi-layered, encompassing both internal and external triggers (Robertson, 2018). While current studies have identified many external factors, be it political, social or economic, the internal factors that impact stakeholder's disagreement are less clear. A further investigation on the internal factors may help to account for the various kinds of contestation and shed light on how to deal with this complex issue.

\subsection{Stakeholders of Contested Heritage}

The stakeholders involved in heritage contestation were discussed in 91 articles out of 102 . Based on their conflicting interests examined within the studies, these stakeholders were classified into six groups (Fig. 9).

[Fig. 9]

The most frequently mentioned stakeholder was the public sector (63 articles), particularly the government and authorities, which was found to be the only sector that had competing interest with every other stakeholder group (Beaumont, 2009; Ingerpuu, 2018; Kouri, 2017; Light, 2000; Zhu, 2015). As a key stakeholder and decision-maker, the public sector in the reviewed articles encountered dissonance at a transnational, national and local level. For countries with a shared history (as a result of war and colonization), contestation of heritage existed between governments from different countries during the process of heritage 
preservation (Beaumont, 2009), nomination (Rico, 2008) and interpretation (Hannam, 2006). In terms of the development of heritage sites, conflicts were also found within the national government (Flynn, 2011; Robertson, 2018) and between national and local government (Henderson, 2001; Zhang \& Wu, 2016). Despite the involvement of other public sectors, including the heritage department, tourism department and planning department, contestation among these divisions were not covered in the studies. As for the conflicts with other stakeholder groups, contestation predominantly occurred between the public sector and local community.

The local community, including residents, indigenous people, ethnic minorities and religious groups, is another key stakeholder group that was discussed in 55 articles, which examined its conflicts with the public sector, private sector, visitors and professionals. The dissonance between the local community and public sector was reflected in a bottom-up approach among residents against the hegemonic power to safeguard their own heritage (Cheung, 1999; Hale, 2001; Putra \& Hitchcock, 2005). Regarding the dissonance with private sector, local community argued against the interpretation of heritage from tourism operators (Banaszkiewicz, 2017; Jacobs, 2010), and was conflicted with developers in terms of heritage conservation (Gadsby \& Chidester, 2011; Wang \& Aoki, 2019). Additionally, the different values attached to heritage resulted in the dissonance between the local community, it's visitors (Kryder-Reid et al., 2018) and professionals (Plets et al., 2013). The most distinctive feature of local community contention was internal discordance, which was present within each community group (Daehnke, 2007; Harrison, 2004; Olsen \& Timothy, 2002; Robertson, 2018).

Professionals, or experts and scholars in relevant fields, are a separate stakeholder group that were studied in 23 articles, regarding their conflicts with the public sector, private sector and local community. The expertise of professionals enabled them to contest the decisions made by the public sector in relation to heritage management (Putra \& Hitchcock, 
2005; Zhu, 2015). Furthermore, professionals and the private sector often had contradicting visions for, and concerns with, developments in heritage (Galbo, 2019; Worden, 1996). In terms of the conflict with local community, professionals usually take the research value of heritage as priority during conservation, which was contested by local community because their interests and needs were neglected (Daehnke, 2007; Plets et al., 2013).

Visitors, which were studied in 21 papers, composed of domestic visitors, international visitors, and diaspora. Diaspora refers to individuals or communities of any national, ethnic or ethno-religious group living outside the physical boundaries of an understood homeland or ancestral territory (Ang, 2011). The dissonance between visitors and the public sector, private sector and local community all revolved around the interpretation of heritage. This dissonance also had some impact on the fate of heritage (Teye \& Timothy, 2004).

The private sector, as discussed in 18 papers, included tourism operators, merchants, heritage site staff, developers and landowners. Its dissonance with the public sector, professionals, NGOs and the local community mainly occurred in response to heritage conservation, however, with visitors, contestation arose as a result the interpretations of heritage, as mentioned previously (Park, 2016; Tucker \& Carnegie, 2014).

NGOs were discussed the least amongst all the stakeholders explored in the texts, despite their essential role in the management of contested heritage (Kouri, 2017). As an active protector of heritage, its conflicts with the public sector and private sector centred around heritage conservation, as examined in 12 of the articles (Esposito \& Fauveaud, 2019; Jones et al., 2017).

Moreover, an unexpected yet noteworthy stakeholder that emerged within the reviewed literature was the media, which was mentioned in 13 articles. Despite not being involved directly in heritage contestation as other stakeholders were, the media played a significant role 
in raising people's awareness of the contestation and providing updates of the latest progress (Zhang \& Li, 2016; Zhu, 2015). It also increased the visibility of the public sector's handling of, and response to, the contested heritage (Beaumont, 2009; Dawson, 2017).

Overall, the many and varied stakeholders confirm the complexity of contested heritage. Additionally, the conflicts between and within stakeholder groups adds further complexity to the issue. Consequently, the significance of stakeholder engagement is stressed in several studies. For example, Nyaupane (2009) addressed a strong need for the various stakeholders to communicate, cooperate and collaborate in order to reduce dissonance amongst the groups. Battilani et al. (2018) argued that sustainable tourism development of dissonant heritage can only be achieved by engaging the local community. Stakeholder engagement is also recognized for its key role in the nomination of UNESCO's World Heritage sites (Harrison, 2004). Although the importance of getting stakeholders involved is well recognized in contested heritage management literature, how to engage the stakeholders, what the expected outcomes of stakeholder's engagement are, and whether stakeholder engagement works in different cultural and political contexts, are some of the managerial and theoretical questions that currently remained unsolved.

\subsection{Features of Contested Heritage}

Despite the various types of contested heritage, four features are deemed intrinsic to contested heritage. The first feature is its multiple stakeholders with conflicting interests. Conflicting interests among these stakeholders make contested heritage a very complex issue as satisfying the interests of one group may compromise the interests of the other. This lack of synergy amongst the different stakeholders' interests was also found in both the urbanization and tourism development process (Wang, 2008; Zhang \& Li, 2016). The discordant interests and objectives within the stakeholder groups makes the issue more complex with various sub- 
divisions trying to exert their visions in this discursive space (Olsen \& Timothy, 2002). Corsale and Krakover (2018) highlighted that even a small minority group that is apparently united and homogeneous, faces dissonance when dealing with historic legacy. This review shows that dissonance among stakeholders is linked to five main factors, namely heritage ownership (Kouri, 2017; Wu, 2019), the value and meaning of heritage (Gadsby \& Chidester, 2011; Shilo \& Collins-Kreiner, 2019), the use of heritage (Dawson, 2017; Su, 2011), heritage interpretation (Gough, 2007; Muzaini, 2017) and heritage authenticity (Bruce \& Creighton, 2006; Zhang \& $\mathrm{Wu}, 2016)$.

The wide range of stakeholders involved in the contestation of heritage, in some ways leads to the second feature, which is the intentional or unintentional marginalization of certain stakeholders. Sometimes, it is inevitable that some less important stakeholders are ignored in heritage management (Flynn, 2011). However, despite encouragement from UNESCO to institutionalize community involvement in the management of heritage sites, 'grassroot stakeholders', in particular, local residents, are deliberately omitted from the management process by the decision-makers (Kouri, 2017, p. 41). As Yeoh and Kong (1997, p. 53) stated, heritage is 'a repository of elite or state power' wherein the dynamic power relations are reflected. Within the context of China, the marginalization of community-level stakeholders is comparatively salient, as a result of its top-down management system. Heritage in China is under a hierarchical and centralized state administration. Therefore, government plays a leading role in the protection, utility and management of heritage (Zhu, 2015). Despite the topdown governmentality and lack of community engagement, residents who are seeking involvement in heritage management in China are beginning to advocate for a shift toward a bottom-up approach (Yan, 2015).

Contested heritage is also dynamic because heritage itself is a product of contemporary times (Tunbridge \& Ashworth, 1996). Since heritage is used to 'construct, reconstruct and 
negotiate a range of identities, and social and cultural values and meanings in the present' (Smith, 2006, p. 3), the memory and meaning attached to the heritage may vary from generation to generation, which means contestation over heritage is ever-shifting (Harrison, 2004a). Therefore, balancing the conservation of contested heritage with the inevitability of change as part of this dynamic process, will always be a very complex and challenging task.

The last intrinsic feature of contested heritage is the lack of strategies available to cope with contestation. Few articles presented strategies to address this issue and of those that did, most strategies attempted to address the lack of agreement with specific focus on heritage meaning and interpretation. For example, Nauert (2017) presented a constructive bottom-up approach to integrate diverse narratives. Instead of creating a fixed overall narrative, this approach focused on an inclusive process that involved various stakeholders acting as active interpreters in the construction of their own knowledge. Using technology as a strategy was explored by Lemelin and Johansen (2014) who found that the incorporation of QR code in dissonant heritage sites provided an opportunity to enable interpretative narratives to be communicated to visitors, and thus helping resolve some of the contention over heritage. The emergence of virtual heritage applications was also found to be helpful as they act as 'neutral and adaptive tools that allow different stories to appear side by side' (Selim et al., 2017, p. 161). Another strategy commonly mentioned in the literature focused on the involvement of various stakeholders in heritage management (Weisse \& Ross, 2017), despite the difficulties of true citizen empowerment in practice (Thomas \& Banks, 2019).

The features of contested heritage indicate the key role of stakeholder in its management, and thus it is important for future studies to shift the focus from heritage itself to its stakeholders. Current studies have made it evident that multiple stakeholders with different value perceptions and interests are embedded in contested heritage. Therefore, more research is needed to characterize the stakeholders and better understand their motivations, perspectives 
and expectations. Moreover, stakeholder systems are not just a set of isolated actors, they are subjected to continuous interactions. As such, placing more emphasis on the interrelationships between stakeholders and how their relationships influence heritage contestation could greatly benefit the literature to produce a fuller picture of the complexities embedded within contested heritage. It may also provide further information that could help better coordinate the relationships between these stakeholders to mitigate contestation. Additionally, the cultural context within which contestation occurs is also a significant factor to be considered as culture impacts the understanding and management of heritage. For example, Byrne (2011) noticed that in Asia, but particularly in China, culture connotation plays a more important role in heritage conservation than material forms of the heritage site. Differing from the Western heritage practices in which inheritance is constructed through stone material to overcome the erosion of time, the Chinese tend to inhabit inheritance in the intangible part of heritage, such as rituals and folklore (Zhu, 2015). Although it is too simplistic to reduce the tangibleintangible dichotomy in heritage to an East-West division, it is important to acknowledge the significant influence culture has on the knowledge and values to understand contested heritage.

\subsection{Theoretical Perspective and Contribution}

The theoretical perspective of this review captures the extent to which contested heritage research applies theories, conceptual frameworks and models to motivate and guide its investigations. It demonstrates that most articles exploring the topic lack discerning theoretical development, and that those which do explicitly use theoretical perspectives are relatively recent. The theories mentioned the most were Smith's (2006) authorized heritage discourse (AHD) and Tunbridge and Ashworth's (1996) heritage dissonance. These two heritage theories offer specific perspectives to examine heritage contestation in terms of power relations, and the dissonant nature of heritage (Maior-Barron, 2019; Pavličìć, 2006). Since heritage is a social 
process (Harvey, 2001), several sociological theories have been used to analyse contested heritage also. These theories include post-colonial theory (Hannam, 2006), practice theory (Plets et al., 2013), collective memory theory (Yankholmes \& McKercher, 2015), social movement theory (Jones et al., 2017), identity process theory (Battilani et al., 2018), and international relations theory (Nakano, 2018). In addition, theoretical perspectives from the disciplines of anthropology, management, culture and economics were utilized by the researchers to provide further insights into contested heritage management. Examples include heritage proximity (Nyaupane, 2009), stakeholder collaboration (Suntikul \& Jachna, 2013), globalization theory (Pocock \& Lilley, 2017), ontological turn (Van Dyke, 2017), and neoliberalism (Galbo, 2019).

The theoretical contribution, which captures the extent to which the reviewed articles add novel and substantive theoretical insights to the extant literature, indicates that most of the reviewed articles borrowed theories from external sources. Several articles employed inductive approaches to advance novel concepts or theoretical frameworks. Graham (2002) introduced a knowledge-based approach for heritage regeneration in cities. Al Rabady (2013) proposed a theoretical framework that enables reconciliation between the official/civic nexus and stimulates creative urban images and identities simultaneously. Shilo and Collins-Kreiner (2019) developed a framework for analysing conflicts in heritage tourism sites. In addition, Hall (2019) advanced a concept of 'heritage prospecting' to explain the constant formation, emergence, and expansion of heritage as a politicized and flexible resource (p. 333); and Esposito and Fauveaud (2019) raised the issue of 'atomization of heritage politics' (p. 671).

Despite the limited theoretical contribution generated from the reviewed articles, certain theoretical insights were indicated for future research. For example, in Yan's (2015) study, the knowledge/power nexus was examined to show how knowledge is used as a form of power. Thus, other types of power may need to be further explored to better understand how 
they influence heritage contestation. Jones et al. (2017) highlighted the significant role structure and agency analysis can have in the investigation of heritage contestation, utilizing the actor-network approach to analyse the social and material relations of stakeholders. In addition, the work of Thomas and Banks (2019) mentioned several community involvement models which could be further explored to assist stakeholders in better engagement with heritage management decisions.

Although contested heritage research largely lacks theoretical perspectives, recent studies have witnessed a growth in theory-oriented contributions. These studies use a wide spectrum of theoretical perspectives from different disciplines to reveal the multiple layers of this complex issue. The use of external theories does contribute to the research of contested heritage, however, specialized frameworks and models for contested heritage should be developed to complement, consolidate and enhance extant literature to create a stronger knowledge base. Furthermore, despite the significant theoretical insights provided by the current literature, most of them are used to explain heritage contestation. Little progress has been made to offer insights that help to cope with contested heritage. Therefore, research focusing on testing, extending and integrating theoretical modes and frameworks that help manage contested heritage should be explored further in the future.

\section{Conclusion}

This paper presents a systematic review of contested heritage literature to gain a holistic understanding of this issue. The study covers 102 articles published in 58 journals prior to 2020 . The results demonstrate the diversity and complexity of contested heritage. The diversity of the topic is reflected in the various factors that lead to heritage contestation and the different contexts in which contestation occurs. This diversity provides reason for the lack of a consolidated understanding of this topic, and indicates the need for studies to broaden the scope 
of their investigation to generalize the issue. Despite the necessity to be aware of the specific contexts in which heritage contestation occurs, focussing solely on this provides little insight into ways to cope with the problem with consideration of its diversity. The multiplicity of stakeholders and their discordance in different heritage development stages demonstrates the complexity of contested heritage. The dynamic nature of heritage adds another layer to its complexity. Therefore, studies should not only focus on stakeholders with a special emphasis on understanding how their positions and relations are shaped by the contested heritage, but also with consideration for the shifting values and needs of stakeholders.

This research also shows that tourism and urbanization are triggers of contested heritage. The booming tourism industry which regards heritage as a core resource has caused a major contestation especially in terms of packaging the past (Baillie et al., 2010). The rapid urban development which involves a level of devastation, ruination, and forced resettlement also poses threat to the longevity and security of heritage (Al-Houdalieh \& Sauders, 2009). However, both tourism and urbanism could be valuable conceptual and empirical frames to understand the multiple facets of contested heritage. The contestation over heritage caused by urbanization and tourism suggests the need to reconcile heritage management with urban development and tourism. However, neither the topic of heritage and urbanization, nor the subject of heritage and tourism, is new. The continuous contestation which urbanization and tourism bring to heritage over the two decades should prompt reflection on the significance of the issue and the impact of current research in practice.

By examining theoretical issues, it is found that there is a general lack of theoretically grounded research and theoretical contributions amongst the reviewed literature. This indicates the need to expand the knowledge base of contested heritage. Researchers in recent studies are more prone to apply theories from different fields. These studies bring diversified theoretical perspectives to understand contested heritage and provide a more complex conceptualization 
of heritage as contested by capital, memory and identity (Ivanova, 2017; Su, 2010; Van Dyke, 2017). Of concern, however, is the lack of research that elaborates on how to pacify contestation through frameworks that offer solutions, and promote sustainable and harmonious developments in contested heritage. Thus, the managerial practice of contested heritage warrants closer examination in the future.

According to Petticrew and Roberts (2006), a systematic review has its own limitations due to its retrospective, observational, and selective nature. This research is not exempt from limitations. First, only academic journal articles which are available online were examined in this review. Future research including valuable grey literature may offer additional insights into the topic. Second, heritage is not a highly specialized terminology, it is a common expression broadly used across various fields. Therefore, to eliminate irrelevant literature and enhance the precision of the resultant literature, the search was restricted to title, abstract, and keywords in the selection process. Consequently, studies that have considered contested heritage but do not mention the search terms in any of the three sections may have been overlooked. It is recommended that future researchers should be prudent in their studies to achieve a balance between comprehensiveness and precision when conducting their systematic literature review. Finally, key words used as a starting point in this research were different derivatives of the word 'contested'. Noticing the popularity of the term 'dissonant' in the reviewed literature and its slight difference in meaning from 'contested' on the spectrum of negativity, a further review with a focus on 'dissonant' in the search term is encouraged to compare the findings with this review.

Despite the limitations, this review has demonstrated the multi-faceted nature of contested heritage and developed a foundation for future researchers to collaboratively present a more comprehensive and holistic view of the topic. Based on the findings from the review, the following recommendations are provided for future research. First, since stakeholder 
groups are not just a set of isolated actors but subjected to continuous interactions, future research could focus not only on stakeholders per se but also on their interrelationship or network. This is crucial for a more nuanced account of heritage contestation and a better understanding of the mechanism of contestation that significantly influence decision-making and policy-makers. Second, despite the growing consensus on the importance of a multistakeholder approach when dealing with contested heritage (Kimbu \& Ngoasong, 2013; Pacifico \& Vogel, 2012), there is limited knowledge of how decision-makers can approach and engage all stakeholders effectively. For example, to what extent should different stakeholder groups be involved? What are the expected outcomes of stakeholder engagement? The multistakeholder approach requires an understanding of not only stakeholder attributes but also the factors that drive or impede their engagement in contested heritage management. Focusing on those factors in the early stage of a contested development may contribute to the change of current frameworks dealing with contested heritage and renew methods for a more positive outcome. Further, heritage contestation is an inevitable part of globalization, which also opens up potential for new types of contestation to develop due to the fact that dominant Western paradigms may not fit into the context of non-Western cultures (Matsuda \& Mengoni, 2016). Future research is encouraged to explore cultural pluralism and its translation. The investigation of how heritage is shaped and reshaped by different cultures enables an understanding of the similarities and differences between heritage contestation in a Western and non-Western context to be foregrounded, while also revealing how one society is influenced by transcultural factors. 


\section{References}

Al-Houdalieh, S. H., \& Sauders, R. R. (2009). Building destruction: The consequences of rising urbanization on cultural heritage in the Ramallah province. International Journal of Cultural Property, 16(1), 1-23.

Al Quntar, S., \& Daniels, B. I. (2016). Responses to the destruction of Syrian cultural heritage: A critical review of current efforts. International Journal of Islamic Architecture, 5(2), 381-397.

Al Rabady, R. (2013). Creative cities through local heritage revival: A perspective from Jordan/Madaba. International Journal of Heritage Studies, 19(3), 288-303.

Ang, I. (2011). Unsettling the national: Heritage and diaspora. In H. Anheier, D. Viejo-Rose, \& Y. R. Isa (Eds.), Heritage, memory and identity: The cultures and globalisation series (pp. 82-94). Sage.

Ashworth, G. J. (2002). Holocaust tourism: The experience of Kraków-Kazimierz. International Research in Geographical and Environmental Education, 11(4), 363-367.

Ashworth, G. J. (2014). Heritage and economic development: Selling the unsellable. Heritage \& Society, 7(1), 3-17.

Ashworth, G. J., \& Tunbridge, J. E. (2000). The tourist-historic city. Routledge.

Avni, N., \& Teschner, N. A. (2019). Urban Waterfronts: Contemporary streams of planning conflicts. Journal of Planning Literature, 34(4), 408-420.

Baillie, B., Chatzoglou, A., \& Taha, S. (2010). Packaging the past: The commodification of heritage. Heritage Management, 3(1), 51-71.

Banaszkiewicz, M. (2017). A dissonant heritage site revisited-the case of Nowa Huta in Krakow. Journal of Tourism and Cultural Change, 15(2), 185-197.

Battilani, P., Bernini, C., \& Mariotti, A. (2018). How to cope with dissonant heritage: A way towards sustainable tourism development. Journal of Sustainable Tourism, 26(8), 1417-1436.

Beaumont, J. (2009). Contested trans-national heritage: The demolition of Changi Prison, Singapore. International Journal of Heritage Studies, 15 (4), 298-316.

Best, M. N., \& Phulgence, W. F. (2013). Interpretation of contested heritage at an attraction in St. Lucia. Journal of Heritage Tourism, 8(1), 21-35.

Bofulin, M. (2017). Building memorials for a friend or a foe? Mobility and heritage dissonance amid China-Japan conflict. Anthropological Notebooks, 23(3), 45-61. 
Brosché, J., Legnér, M., Kreutz, J., \& Ijla, A. (2017). Heritage under attack: Motives for targeting cultural property during armed conflict. International Journal of Heritage Studies, 23(3), 248-260.

Bruce, D., \& Creighton, O. (2006). Contested identities: The dissonant heritage of European town walls and walled towns. International Journal of Heritage Studies, 12(3), 234254.

Butler, R. W. (1980). The concept of a tourist area cycle of evolution: Implications for management of resources. Canadian Geographer/Le Géographe canadien, 24(1), 512.

Byrne, D. (2011). Thinking about popular religion and heritage. In J. N. Miksic, G. Y. Goh, \& S. O'Connor (Eds.), Rethinking cultural resource management in Southeast Asia: Preservation, development, and neglect (pp. 3-14). Anthem Press.

Carr, G. (2010). Shining a light on dark tourism: German bunkers in the British Channel Islands. Public Archaeology, 9(2), 64-84.

Chen, F., \& Mele, C. (2017). Film-induced pilgrimage and contested heritage space in Taipei City. City, Culture and Society, 9, 31-38.

Cheung, S. C. (1999). The meanings of a heritage trail in Hong Kong. Annals of Tourism Research, 26(3), 570-588.

Chinyele, B. J., \& Lwoga, N. B. (2019). Participation in decision making regarding the conservation of heritage resources and conservation attitudes in Kilwa Kisiwani, Tanzania. Journal of Cultural Heritage Management and Sustainable Development, $9(2), 184-198$.

Cohen, E., \& Cohen, S. A. (2012). Current sociological theories and issues in tourism. Annals of Tourism Research, 39(4), 2177-2202.

Collins, J. A., and Fauser, B. C. (2005). Balancing the strengths of systematic and narrative reviews. Human Reproductive Update, 11 (2), 103-104.

Corsale, A., \& Krakover, S. (2018). Cultural tourism between local and transnational identities: Jewish heritage in Syracuse, Italy. Tourism Geographies, 21(3), 460-481.

Daehnke, J. D. (2007). A ‘Strange Multiplicity’ of voices: Heritage stewardship, contested sites and colonial legacies on the Columbia River. Journal of Social Archaeology, 7(2), 250275. 
Dawood, S. R. S., Ghazali, S., \& Kadir, S. M. A. (2011). Preserving village identity in a globalizing city space: The case of Kampung Dodol, George Town, Penang, Malaysia. International Journal of Arts \& Sciences, 4 (23), 219-230.

Dawson, M. (2017). Roşia Montană: The Road to World Heritage Status. The Historic Environment: Policy \& Practice, 8(1), 25-47.

Esposito, A., \& Fauveaud, G. (2019). The atomization of heritage politics in post-colonial cities: The case of Phnom Penh, Cambodia. Environment and Planning C: Politics and Space, 37(4), 670-688.

Feighery, W. G. (2011). Contested heritage in the ancient city of peace. Historic Environment, 23(1), 38.

Flynn, M. K. (2011). Decision-making and contested heritage in Northern Ireland: The former Maze prison/Long Kesh. Irish Political Studies, 26(3), 383-401.

Fouseki, K., \& Nicolau, M. (2018). Urban heritage dynamics in 'heritage-led regeneration': Towards a sustainable lifestyles approach. The Historic Environment: Policy \& Practice, 9(3-4), 229-248.

Gadsby, D. A., \& Chidester, R. C. (2011). Heritage and 'those people': Representing workingclass interests through Hampden's archaeology. Historical Archaeology, 45(1), 101113.

Galbo, J. (2019). Renovating the Roman Colosseum: Politics, urban restructuring, and the value of heritage in neoliberal times. European Journal of Cultural and Political Sociology, 6(3), 288-316.

Gough, P. (2007). 'Contested memories: contested site': Newfoundland and its unique heritage on the Western Front. The Round Table, 96(393), 693-705.

Graham, B. (1996). The contested interpretation of heritage landscapes in Northern Ireland. International Journal of Heritage Studies, 2(1-2), 10-22.

Graham, B. (2002). Heritage as knowledge: Capital or culture? Urban Studies 39 (5-6), 10031017.

Graham, B. J., \& Howard, P. (Eds.). (2008). The Ashgate research companion to heritage and identity. Ashgate Publishing, Ltd.

Guitart, D., Pickering, C., \& Byrne, J. (2012). Past results and future directions in urban community gardens research. Urban Forestry \& Urban Greening, 11(4), 364-373.

Hale, A. (2001). Representing the Cornish: Contesting heritage interpretation in Cornwall. Tourist Studies, 1(2), 185-196. 
Halevi, M. (2015). Contested heritage: Multi-layered politics and the formation of the sacred space-the church of Gethsemane as a case-study. The Historical Journal, 58(4), 10311058.

Hall, A. C. (2019). Heritage Prospecting and the Past as Future (s) in Peru. The Journal of Latin American and Caribbean Anthropology, 24(2), 331-350.

Hannam, K. (2006). Contested representations of war and heritage at the residency, Lucknow, India. International Journal of Tourism Research, 8 (3), 199-212.

Harrison, D. (2004). Levuka, Fiji: Contested heritage. Current Issues in Tourism, 7(4-5), 346369.

Harrison, D. (2004a). Introduction: Contested narratives in the domain of World Heritage. Current Issues in Tourism, 7(4-5), 281-290.

Harrison, R. (2013). Heritage: Critical approaches. Routledge.

Harvey, D. C. (2001). Heritage pasts and heritage presents: Temporality, meaning and the scope of heritage studies. International Journal of Heritage Studies, 7(4), 319-338.

Hellman, J. (2017). Living together with ancestors: Cultural heritage and sacred places on West Java. International Journal of Religious Tourism and Pilgrimage, 5(1), 78-88.

Henderson, J. (2001). Heritage, identity and tourism in Hong Kong. International Journal of Heritage Studies, 7(3), 219-235.

Hosagrahar, J., Soule, J., Girard, L. F., \& Potts, A. (2016). Cultural heritage, the UN sustainable development goals, and the new urban agenda. BDC. Bollettino Del Centro Calza Bini, 16(1), 37-54.

Ingerpuu, L. (2018). Socialist architecture as today's dissonant heritage: Administrative buildings of collective farms in Estonia. International Journal of Heritage Studies, 24(9), 954-968.

Ivanova, M. (2017). The inclusion of the communist/socialist heritage in the emerging representations of Eastern Europe: The case of Bulgaria. Tourism Culture \& Communication, 17(1), 31-46.

Jacobs, J. (2010). Re-branding the Levant: Contested heritage and colonial modernities in Amman and Damascus. Journal of Tourism and Cultural Change, 8(4), 316-326.

Johnston, C. S. (2001). Shoring the foundations of the destination life cycle model, part 1: Ontological and epistemological considerations. Tourism Geographies, 3(1), 2-28.

Johnson, L. (2014). Renegotiating dissonant heritage: The statue of JP Coen. International Journal of Heritage Studies, 20(6), 583-598. 
Jones, T., Mozaffari, A., \& Jasper, J. M. (2017). Heritage contests: What can we learn from social movements? Heritage \& Society, 10(1), 1-25.

Karoglou, M., Kyvelou, S. S., Boukouvalas, C., Theofani, C., Bakolas, A., Krokida, M., \& Moropoulou, A. (2019). Towards a preservation-sustainability nexus: Applying LCA to reduce the environmental footprint of modern built heritage. Sustainability, 11(21), 6147.

Kimbu, A. N., \& Ngoasong, M. Z. (2013). Centralised decentralisation of tourism development: A network perspective. Annals of Tourism Research, 40, 235-259.

Kisić, V. (2013). Governing heritage dissonance: Promises and realities of selected cultural policies. European Cultural Foundation.

Kouri, M. (2017). Ownership and participation: Democratizing the administration of antiquities. Zarządzanie w kulturze, 18(1), 41-60.

Kryder-Reid, E., Foutz, J. W., Wood, E., \& Zimmerman, L. J. (2018). 'I just don't ever use that word': Investigating stakeholders' understanding of heritage. International Journal of Heritage Studies, 24(7), 743-763.

Lemelin, R. H., \& Johansen, K. (2014). The Canadian National Vimy Memorial: Remembrance, dissonance and resonance. International Journal of Culture, Tourism and Hospitality Research, 8(2), 203-218.

Lemelin, R. H., Whyte, K. P., Johansen, K., Desbiolles, F. H., Wilson, C.\& Hemming, S. (2013). Conflicts, battlefields, indigenous peoples and tourism: Addressing dissonant heritage in warfare tourism in Australia and North America in the twenty-first century. International Journal of Culture, Tourism and Hospitality Research, 7(3), 257-271.

Leung, M. W. (2009). Fates of European heritage in post-colonial contexts: Political economy of memory and forgetting in Hong Kong. Geographische Zeitschrift, 97 (1), 24-42.

Light, D. (2000). An unwanted past: Contemporary tourism and the heritage of communism in Romania. International Journal of Heritage Studies, 6(2), 145-160.

Logan, W. S. (1996). Protecting historic Hanoi in a context of heritage contestation. International Journal of Heritage Studies, 2(1-2), 76-92.

Loulanski, T. (2006). Revising the concept for cultural heritage: The argument for a functional approach. International Journal of Cultural Property 13 (2), 207-233.

Macdonald, S. M. (2013). Memorylands: Heritage and identity in Europe today. Routledge. 
Maior-Barron, D. (2019). Let them eat macarons? Dissonant heritage of Marie Antoinette at Petit Trianon. International Journal of Heritage Studies, 25(2), 198-218.

Malan, A. (2004). Contested sites: Negotiating new heritage practice in Cape Town. Journal for Islamic Studies, 25(1), 17-52.

Marquis-Kyle, P., \& Walker, M. (1992). The Illustrated Burra Charter. Australia ICOMOS.

Matsuda, A., \& Mengoni, L. E. (Eds.). (2016). Reconsidering cultural heritage in East Asia. Ubiquity Press.

Moher, D., Liberati, A., Tetzlaff, J., \& Altman, D. G. (2009). Preferred reporting items for systematic reviews and meta-analyses: The PRISMA statement. Annals of Internal Medicine, 151(4), 264-269.

Muzaini, H. (2017). Informal heritage-making at the Sarawak cultural village, East Malaysia. Tourism Geographies, 19(2), 244-264.

Nakano, R. (2018). A failure of global documentary heritage? UNESCO's 'memory of the world' and heritage dissonance in East Asia. Contemporary Politics, 24(4), 481-496.

Nauert, S. (2017). The linguistic and cultural interpretation of dissonant heritage: The ATRIUM cultural route. Almatourism-Journal of Tourism, Culture and Territorial Development, 8(15), 16-37.

Nuryanti, W. (1996). Heritage and postmodern tourism. Annals of Tourism Research, 23(2), 249-260.

Nyaupane, G. P. (2009). Heritage complexity and tourism: The case of Lumbini, Nepal. Journal of Heritage Tourism, 4(2), 157-172.

Oakes, T. (2013). Heritage as improvement: Cultural display and contested governance in rural China. Modern China, 39(4), 380-407.

Olsen, D. H., \& Timothy, D. J. (2002). Contested religious heritage: Differing views of Mormon heritage. Tourism Recreation Research, 27(2), 7-15.

Owsianowska, S. (2017). Tourist narratives about the dissonant heritage of the borderlands: The case of South-eastern Poland. Journal of Tourism and Cultural Change, 15(2), 167-184.

Pacifico, D., \& Vogel, M. (2012). Archaeological sites, modern communities, and tourism. Annals of Tourism Research, 39(3), 1588-1611.

Park, H. Y. (2016). Tourism as reflexive reconstructions of colonial past. Annals of Tourism Research, 58, 114-127. 
Pavličić, J. (2016). Dissonant heritage and promotion of tourism in the case of Serbian medieval monuments in Kosovo. Journal of Tourism and Cultural Change, 14(3), 189205.

Petticrew, M., \& Roberts, H. (2006). Systematic reviews in the social sciences: A practical guide. Blackwell.

Pickering, C., \& Byrne, J. (2014). The benefits of publishing systematic quantitative literature reviews for $\mathrm{PhD}$ candidates and other early-career researchers. Higher Education Research \& Development, 33(3), 534-548.

Plets, G., Konstantinov, N., Soenov, V., \& Robinson, E. (2013). Repatriation, doxa, and contested heritages: The return of the Altai Princess in an international perspective. Anthropology \& Archaeology of Eurasia, 52(2), 73-98.

Pocock, C., \& Lilley, I. (2017). Who benefits? World heritage and indigenous people. Heritage \& Society, 10(2), 171-190.

Putra, I. N. D., \& Hitchcock, M. (2005). Pura Besakih: A world heritage site contested. Indonesia and the Malay World, 33(96), 225-238.

Rico, T. (2008). Negative heritage: The place of conflict in world heritage. Conservation and Management of Archaeological Sites, 10 (4), 344-352.

Ristic, M., \& Frank, S. (Eds.). (2019). Urban Heritage in Divided Cities: Contested Pasts. Routledge.

Robertson, C. (2018). Celebrating a Scottish past: Construction, contestation and the role of government. World Archaeology, 50(2), 337-346.

Rodenberg, J., \& Wagenaar, P. (2016). Essentializing 'Black Pete': Competing narratives surrounding the Sinterklaas tradition in the Netherlands. International Journal of Heritage Studies, 22(9), 716-728.

Roushanzamir, E. L., \& Kreshel, P. J. (2001). Gloria and Anthony visit a plantation: History into heritage at 'Laura: A creole plantation'. International Journal of Hospitality \& Tourism Administration, 2(3-4), 177-200.

Schramm, K. (2016). African homecoming: Pan-African ideology and contested heritage. Routledge.

Selim, G., Abdelmonem, M. G., Mushatat, S., \& Almogren, A. (2017). Contested heritage: An analysis of the physical transformation of Derry/Londonderry's siege monument. International Journal of Architectural Research: ArchNet-IJAR, 11(3), $146-162$. 
Shilo, S., \& Collins-Kreiner, N. (2019). Tourism, heritage and politics: Conflicts at the City of David, Jerusalem. Asia Pacific Journal of Tourism Research, 24(6), 529-540.

Silverman, H. (2011). Contested cultural heritage: A selective historiography. In H. Silverman (Ed.), Contested cultural heritage: Religion, nationalism, erasure, and exclusion in a global world (pp. 1-49). Springer Science \& Business Media.

Smith, L. (2006). Uses of Heritage. Routledge.

$\mathrm{Su}, \mathrm{X}$. (2011). Heritage production and urban locational policy in Lijiang, China. International Journal of Urban and Regional Research, 35(6), 1118-1132.

Suntikul, W., \& Jachna, T. (2013). Contestation and negotiation of heritage conservation in Luang Prabang, Laos. Tourism Management, 38, 57-68.

Teye, V. B., \& Timothy, D. J. (2004). The varied colors of slave heritage in West Africa: White American stakeholders. Space and Culture, 7(2), 145-155.

Thomas, S., \& Banks, I. (2019). Asset, burden, Cultybraggan. Community site ownership in a Scottish village. Journal of Community Archaeology \& Heritage, 6(1), 51-68.

Timothy, D. J. (2018). Making sense of heritage tourism: Research trends in a maturing field of study. Tourism Management Perspectives, 25, 177-180.

Timothy, D. J., \& Nyaupane, G. P. (Eds.). (2009). Cultural heritage and tourism in the developing world: A regional perspective. Routledge.

Thompson, K. (2004). Post-colonial politics and resurgent heritage: The development of Kyrgyzstan's heritage tourism product. Current Issues in Tourism, 7(4-5), 370-382.

Tucker, H., \& Carnegie, E. (2014). World heritage and the contradictions of 'universal value'. Annals of Tourism Research, 47, 63-76.

Tunbridge, J. E., \& Ashworth, G. J. (1996). Dissonant heritage: The management of the past as a resource in conflict. Wiley.

Van Dyke, R. M. (2017). Durable stones, mutable pasts: Bundled memory in the Alsatian community of Castroville, Texas. Journal of Archaeological Method and Theory, 24(1), 10-27.

Wang, S. Y. (2008). A mirror with two sides-heritage development and urban conservation in the Ancient City of Pingyao, China. Historic Environment, 21(3), 22-26.

Wang, X., \& Aoki, N. (2019). Paradox between neoliberal urban redevelopment, heritage conservation, and community needs: Case study of a historic neighbourhood in Tianjin, China. Cities, 85, 156-169. 
Weisse, A., \& Ross, A. (2017). Managing a contested cultural heritage place on K'gari (Fraser Island), Queensland, Australia. Archaeology in Oceania, 52(3), 149-160.

While, A. (2007). The state and the controversial demands of cultural built heritage: Modernism, dirty concrete, and postwar listing in England. Environment and Planning B: Planning and Design, 34(4), 645-663.

Worden, N. (1996). Contested heritage at the Cape Town waterfront. International Journal of heritage studies, 2(1-2), 59-75.

$\mathrm{Wu}, \mathrm{S}$. (2019). To share or not to share: Contested heritage in Inner Mongolia, China-A case of overtone singing (khoomei). International Journal of Heritage Studies, 26(3), 267280.

Yamasaki, Y. (2010). Conflicted attitudes toward heritage: Heritage language learning of returnee adolescents from Japan at a Nikkei school in Lima, Peru. Critical Asian Studies, 42(1), 89-110.

Yan, H. (2015). World Heritage as discourse: Knowledge, discipline and dissonance in Fujian Tulou sites. International Journal of Heritage Studies, 21(1), 65-80.

Yankholmes, A., \& McKercher, B. (2015). Rethinking slavery heritage tourism. Journal of Heritage Tourism, 10(3), 233-247.

Yeoh, B., \& Kong, L. (1997). The notion of place in the construction of history, nostalgia and heritage in Singapore. Singapore Journal of Tropical Geography, 17(1), 52-65.

Zhang, C., \& Li, X. (2016). Urban redevelopment as multi-scalar planning and contestation: The case of Enning Road project in Guangzhou, China. Habitat International, 56, 157165.

Zhang, R., \& Smith, L. (2019). Bonding and dissonance: Rethinking the Interrelations Among Stakeholders in Heritage Tourism. Tourism Management, 74, 212-223.

Zhang, Y., \& Wu, Z. (2016). The reproduction of heritage in a Chinese village: Whose heritage, whose pasts? International Journal of Heritage Studies, 22(3), 228-241.

Zhu, Y. (2015). Cultural effects of authenticity: Contested heritage practices in China. International Journal of Heritage Studies, 21(6), 594-608.

Zhu, Y. (2018). Uses of the past: Negotiating heritage in Xi'an. International Journal of Heritage Studies, 24(2), 181-192. 
Table 1. Definitions given in the collected articles (Original definition of dissonant heritage was provided on the top of the table)

\begin{tabular}{|c|c|c|c|}
\hline No. & Author (Year) & Definition & Journal \\
\hline & $\begin{array}{l}\text { Tunbridge } \\
\text { \&Ashworth } \\
\text { (1996) }\end{array}$ & $\begin{array}{l}\text { The heritage creation process is controversial in a number of } \\
\text { respects...The idea of dissonance... keeps at the forefront the ideas } \\
\text { of discrepancy and incongruity. Dissonance in heritage involves a } \\
\text { discordance or a lack of agreement and consistency... [Also, the } \\
\text { concept implies] a state of psychic tension caused by the } \\
\text { simultaneous holding of mutually inconsistent attitudes or the } \\
\text { existence of a lack of consonance between attitudes and } \\
\text { behaviour... [Dissonance] is intrinsic to the nature of } \\
\text { heritage ....At its simplest, all heritage is someone's heritage and } \\
\text { therefore logically not someone else's. (Tunbridge \& Ashworth, } \\
\text { 1996, pp.20-21) }\end{array}$ & \\
\hline 1 & $\begin{array}{l}\text { Ashworth } \\
(2002)\end{array}$ & $\begin{array}{l}\text { Dissonant heritage is a condition in which there is a lack of } \\
\text { congruence in time or space between people and their heritage } \\
\text { (Tunbridge \& Ashworth, 1996). }\end{array}$ & $\begin{array}{l}\text { International Research } \\
\text { in Geographical and } \\
\text { Environmental } \\
\text { Education }\end{array}$ \\
\hline 2 & $\begin{array}{l}\text { Graham } \\
\text { (2002) }\end{array}$ & $\begin{array}{l}\text { Tunbridge and Ashworth's thesis of dissonant heritage (1996) } \\
\text { represents the most sustained attempt to conceptualize this facet of } \\
\text { heritage and its repercussions. Dissonance is a condition that refers } \\
\text { to the discordance or lack of agreement and consistency as to the } \\
\text { meaning of heritage. }\end{array}$ & Urban Studies \\
\hline 3 & $\begin{array}{l}\text { Bruce \& } \\
\text { Creighton } \\
(2006)\end{array}$ & $\begin{array}{l}\text { Town walls can be conceptualized as a 'dissonant' form of } \\
\text { heritage whose value is contested between different interest groups } \\
\text { and whose meanings are not static but can be rewritten. }\end{array}$ & $\begin{array}{l}\text { International Journal } \\
\text { of Heritage Studies }\end{array}$ \\
\hline 4 & $\begin{array}{l}\text { Nyaupane } \\
(2009)\end{array}$ & $\begin{array}{l}\text { According to Tunbridge and Ashworth (1996), 'Dissonance in } \\
\text { heritage involves a discordance or lack of agreement and } \\
\text { consistency (p. 2).' }\end{array}$ & $\begin{array}{l}\text { Journal of Heritage } \\
\text { Tourism }\end{array}$ \\
\hline 5 & $\mathrm{Su}(2011)$ & $\begin{array}{l}\text { The notion of dissonant heritage, developed by Tunbridge and } \\
\text { Ashworth (1996), illustrates a concerted effort to conceptualize the } \\
\text { contested nature of heritage through a focus on the mismatch and } \\
\text { disagreement between different groups of people towards the } \\
\text { meaning and use of heritage. }\end{array}$ & $\begin{array}{l}\text { International Journal } \\
\text { of Urban and } \\
\text { Regional Research }\end{array}$ \\
\hline 6 & $\begin{array}{l}\text { Lemelin et al. } \\
\text { (2013) }\end{array}$ & $\begin{array}{l}\text { Dissonant heritage is defined as the perpetuation of grand colonial } \\
\text { narratives in Australia, North America and elsewhere which have } \\
\text { resulted in the general omission of indigenous narratives from } \\
\text { discourse about, and interpretation and development at, many sites } \\
\text { associated with battlefield, dark or warfare tourism. }\end{array}$ & $\begin{array}{l}\text { International Journal } \\
\text { of Culture, Tourism } \\
\text { and Hospitality } \\
\text { Research }\end{array}$ \\
\hline 7 & Johnson (2014) & $\begin{array}{l}\text { The concept of 'dissonant heritage', introduced by Tunbridge and } \\
\text { Ashworth (1996), examined the ways in which the past can be used } \\
\text { as a resource in present conflict situations. }\end{array}$ & $\begin{array}{l}\text { International Journal } \\
\text { of Heritage Studies }\end{array}$ \\
\hline 8 & $\begin{array}{l}\text { Yankholmes \& } \\
\text { McKercher } \\
(2015)\end{array}$ & $\begin{array}{l}\text { Thus, dissonant heritage sites, places whose value is contested } \\
\text { between different interest groups and whose meanings are not } \\
\text { static but can be rewritten (Bruce \& Creighton, 2006), are } \\
\text { especially problematic, for the entire debate about the meaning and } \\
\text { resultant use of the site is unresolved. }\end{array}$ & $\begin{array}{l}\text { Journal of Heritage } \\
\text { Tourism }\end{array}$ \\
\hline
\end{tabular}




\begin{tabular}{|c|c|c|c|}
\hline 9 & Pavličić (2016) & $\begin{array}{l}\text { Significant parts of the heritage became 'dissonant heritage', } \\
\text { which according to Tunbridge and Ashworth }(1996, \text { p. 27) is } \\
\text { related to the process of coping with ambivalent and largely } \\
\text { unwanted pasts. }\end{array}$ & $\begin{array}{l}\text { Journal of Tourism } \\
\text { and Cultural Change }\end{array}$ \\
\hline 10 & $\begin{array}{l}\text { Banaszkiewicz } \\
(2017)\end{array}$ & $\begin{array}{l}\text { Therefore, probably the more appropriate term which could be } \\
\text { applied here is dissonant heritage (Ashworth, 2002, pp. 363-364) } \\
\text { which 'generally means a lack of harmony in time and space } \\
\text { between people and their heritage'. }\end{array}$ & $\begin{array}{l}\text { Journal of Tourism } \\
\text { and Cultural Change }\end{array}$ \\
\hline 11 & Nauert (2017) & $\begin{array}{l}\text { 'Dissonant heritage', according to Tunbridge and Ashworth } \\
\text { (1996) refers to a contrast of meaning and value systems between } \\
\text { past and present. }\end{array}$ & $\begin{array}{l}\text { Journal of Tourism, } \\
\text { Culture and } \\
\text { Territorial } \\
\text { Development }\end{array}$ \\
\hline 12 & $\begin{array}{l}\text { Owsianowska } \\
(2017)\end{array}$ & $\begin{array}{l}\text { According to the well-known concept of dissonant heritage, } \\
\text { brought forward by Tunbridge and Ashworth (1996) and } \\
\text { formulated in the context of heritage and tourism management, } \\
\text { dissonance is 'a condition that refers to the discordance or lack of } \\
\text { agreement and consistency as to the meaning of heritage' } \\
\text { (Ashworth, Graham \& Tunbridge, 2007, p. 3). }\end{array}$ & $\begin{array}{l}\text { Journal of Tourism } \\
\text { and Cultural Change }\end{array}$ \\
\hline 13 & $\begin{array}{l}\text { Corsale \& } \\
\text { Krakover } \\
(2018)\end{array}$ & $\begin{array}{l}\text { Timothy and Nyaupane (2009) use the term 'contested heritage' to } \\
\text { describe cases of conflicts between different social groups over the } \\
\text { same relics, sites and events, where each group (or even sub- } \\
\text { group) claims them as their own heritage, interprets them } \\
\text { differently, and aims to use them for different purposes. }\end{array}$ & Tourism Geographies \\
\hline 14 & $\begin{array}{l}\text { Maior-Barron } \\
(2019)\end{array}$ & $\begin{array}{l}\text { Referencing the concept of dissonant heritage (Tunbridge \& } \\
\text { Ashworth, 1996), this is: the discordance or lack of agreement and } \\
\text { consistency as to the meaning of heritage. }\end{array}$ & $\begin{array}{l}\text { International Journal } \\
\text { of Heritage Studies }\end{array}$ \\
\hline
\end{tabular}

\section{Annex 1}

\begin{tabular}{|l|l|}
\hline \multicolumn{1}{|c|}{ Topics } & \multicolumn{1}{|c|}{ Authors } \\
\hline $\begin{array}{l}\text { Contestation } \\
\text { in different } \\
\text { tourism } \\
\text { stages }\end{array}$ & $\begin{array}{l}\text { Al Rabady, 2013; Anson, 1999; Ashworth, 2002; Ashworth \& Ashworth, } \\
\text { 1998; Banaszkiewicz, 2017; Battilani et al., 2018; Beaumont, 2009; Best \& } \\
\text { Phulgence, 2013; Bofulin, 2017; Buchholtz, 2005; Calum, 2018; Carr, 2010; } \\
\text { Chang \& Teo, 2009; Chen \&Mele, 2017; Cheung, 1999; Corsale \& Krakover, } \\
\text { 2018; Creighton, 2007; Dawson, 2017; Esposito \& Fauveaud, 2019; } \\
\end{array}$ \\
& $\begin{array}{l}\text { Feighery, 2011; Förster et al., 2016; Galbo, 2019; Gough, 2007; Graham, } \\
\text { Hellman, 2017; Henderson, 2001; Hökerberg, 2017; Ivanova, 2017; Jacobs, }\end{array}$ \\
\hline
\end{tabular}




\begin{tabular}{|c|c|}
\hline & $\begin{array}{l}\text { 2010; Johnson, 2014; Kouri, 2017; Kryder-Reid et al., 2018; Lemelin \& } \\
\text { Johansen, 2014; Lemelin et al., 2019; Light, 2000; Malan, 2004; Murtagh et } \\
\text { al., 2017, Muzaini, 2017; Nasser, 2003; Nauert, 2017; Nyaupane, 2009; } \\
\text { Oakes, 2013; Øian, 2019; Olsen \& Timothy, 2002; Owsianowska, 2017; } \\
\text { Park, 2016; Pavličìc, 2016; Pocock \& Lilley, 2017; Putra \& Hitchcock, 2005; } \\
\text { Rakic \& Chambers, 2008; Rickly-Boyd, 2015; Rico, 2008; Shilo \& Collins- } \\
\text { Kreiner, 2019; Su, 2011; Suntikul \& Jachna, 2013; Teye \& Timothy, 2004; } \\
\text { Thompson, 2004; Timothy \& Prideaux, 2004; Tucker \& Carnegie, 2014; Van } \\
\text { Dyke, 2017; Wang, 2008; Weisse \& Ross, 2017; Worden, 1999; Yan, 2015; } \\
\text { Yankholmes \& McKercher, 2015; Zhang \& Wu, 2016; Zhu, 2015; Zhu, } 2018 .\end{array}$ \\
\hline $\begin{array}{l}\text { Contestation } \\
\text { in different } \\
\text { management } \\
\text { status }\end{array}$ & $\begin{array}{l}\text { Al Rabady, 2013; Anson, 1999; Ashworth, 2002; Ashworth \& Ashworth, } \\
\text { 1998; Banaszkiewicz, 2017; Beaumont, 2009; Best \& Phulgence, 2013; } \\
\text { Bofulin, 2017; Boyle, 2019; Bruce \& Creighton, 2006; Buchholtz, 2005; } \\
\text { Calum, 2018; Carr, 2010; Chang \& Teo, 2009; Chen \& Mele, 2017; Cheung, } \\
\text { 1999; Corsale \& Krakover, 2018; Creighton, 2007; Daehnke, 2007; Dawood } \\
\text { et al, 2011; Dawson, 2017; Esposito \& Fauveaud, 2019; Feighery, 2011; } \\
\text { Flynn, 2011; Förster et al., 2016; Frei, 2019; Gadsby \& Chidester, 2011; } \\
\text { Galbo, 2019; Gough, 2007; Graham, 1996; Hale, 2001; Halevi, 2015; Hall, } \\
\text { 2019; Hannam, 2006; Harrison, 2004; Hellman, 2017; Henderson, 2001; } \\
\text { Hökerberg, 2017; Ingerpuu, 2018; Jacobs, 2010; Johnson, 2014; Jones et al., } \\
\text { 2017; Kouri, 2017; Kryder-Reid et al., 2018; Lemelin \& Johansen, 2014; } \\
\text { Lemelin et al., 2013; Leung, 2009; Light, 2000; Logan, 1996; Maior-Barron, } \\
\text { 2019; Malan, 2004; Mataga, 2019; Mitterhofer, 2013; Murtagh et al., 2017; } \\
\text { Muzaini, 2017; Nakano, 2018; Nauert, 2017; Nyaupane, 2009; Oakes, 2013; } \\
\text { Øian, 2019; Olsen \& Timothy, 2002; Owsianowska, 2017; Park, 2016; } \\
\text { Pavličìc, 2016; Plets et al., 2013; Pocock \& Lilley, 2017; Putra \& Hitchcock, } \\
\text { 2005; Rakic, 2008; Rickly-Boyd, 2015; Rico, 2008; Rodenberg \& Wagenaar, } \\
\text { 2016; Selim et al., 2017; Shilo \& Collins-Kreiner, 2019; Su, 2011; Suntikul } \\
\text { \& Jachna, 2013; Teye \& Timothy, 2004; Thomas \& Banks, 2019; Thompson, } \\
\text { 2004; Tucker \& Carnegie, 2014; Van Dyke, 2017; Wang, 2008; Wang \& } \\
\text { Aoki, 2019; Weisse \& Ross, 2017; Worden, 1999; Wu, 2019; Yan, 2015; } \\
\text { Yamasaki, 2010; Yankholmes \& McKercher, 2015; Zhang \& Li, 2016; } \\
\text { Zhang \& Wu, 2016; Zhu, 2015; Zhu, 2018. }\end{array}$ \\
\hline
\end{tabular}




\begin{tabular}{|c|c|}
\hline $\begin{array}{l}\text { Stakeholders } \\
\text { of contested } \\
\text { heritage }\end{array}$ & $\begin{array}{l}\text { Al Rabady, 2013; Anson, 1999; Ashworth, 2002; Ashworth \& Ashworth, } \\
\text { 1998; Avni \& Teschner, 2019; Banaszkiewicz, 2017; Battilani et al., 2018; } \\
\text { Beaumont, 2009; Best \& Phulgence, 2013; Bofulin, 2017; Boyle, 2019; } \\
\text { Bruce \& Creighton, 2006; Buchholtz, 2005; Calum, 2018; Carr, 2010; Chang } \\
\text { \& Teo, 2009; Chen \& Mele, 2017; Cheung, 1999; Corsale \& Krakover, 2018; } \\
\text { Daehnke, 2007; Dawood et al., 2011; Dawson, 2017; Esposito \& Fauveaud, } \\
\text { 2019; Feighery, 2011; Flynn, 2011; Förster et al., 2016; Frei, 2019; Gadsby } \\
\text { \& Chidester, 2011; Galbo, 2019; Gough, 2007; Graham, 1996; Hale, 2001; } \\
\text { Halevi, 2015; Hall, 2019; Hannam, 2006; Harrison, 2004; Hellman, 2017; } \\
\text { Henderson, 2001; Hökerberg, 2017; Ingerpuu, 2018; Ivanova, 2017; Jacobs, } \\
\text { 2010; Johnson, 2014; Jones et al., 2017; Kouri, 2017; Kryder-Reid et al., } \\
\text { 2018; Lemelin \& Johansen, 2014; Lemelin et al., 2013; Leung, 2009; Light, } \\
\text { 2000; Light \& Dumbraveanu-Andone, 1997; Logan, 1996; Maior-Barron, } \\
\text { 2019; Malan, 2004; Mataga, 2019; Mitterhofer, 2013; Murtagh et al., 2017; } \\
\text { Muzaini, 2017; Nakano, 2018; Nyaupane, 2009; Oakes, 2013; Øian, 2019; } \\
\text { Olsen \& Timothy, 2002; Owsianowska, 2017; Park, 2016; Pavličìc, 2016; } \\
\text { Plets et al., 2013; Pocock \& Lilley, 2017; Putra \& Hitchcock, 2005; Rickly- } \\
\text { Boyd, 2015; Rico, 2008; Selim et al., 2017; Shilo \& Collins-Kreiner, 2019; } \\
\text { Su, 2011; Suntikul \& Jachna, 2013;Teye \& Timothy, 2004; Thomas \& Banks, } \\
\text { 2019; Thompson, 2004; Tucker \& Carnegie, 2014; Van Dyke, 2017; Wang, } \\
\text { 2008; Wang \& Aoki, 2019; Weisse \& Ross, 2017; Worden, 1999; Wu, 2019; } \\
\text { Yan, 2015; Yamasaki, 2010; Yankholmes \& McKercher, 2015; Yeoh, 2001; } \\
\text { Zhang \& Li, 2016; Zhang \& Wu, 2016; Zhu, 2015; Zhu, 2018. }\end{array}$ \\
\hline
\end{tabular}

